\begin{tabular}{c} 
International Journal of Engineering \& Technology, $7(2.29)(2018)$ 379-382 \\
International Journal of Engineering \& Technology \\
SPC \\
Website: www.sciencepubco.com/index.php/IJET \\
Research paper \\
\hline
\end{tabular}

\title{
Patients Satisfaction Based on Corporate Entrepreneurship
}

\author{
Ririn Tri Ratnasaria $^{1, *}$, Ari Prasetyo ${ }^{1}$, Masmira Kurniawati ${ }^{1}$, Eko Fajar Cahyono ${ }^{1}$ \\ ${ }^{1}$ department Of Economics, Faculty Of Economics And Business, Universitas Airlangga \\ *Corresponding Author E-Mail: Ririnsari@ Feb.Unair.Ac.Id
}

\begin{abstract}
This research aim to determine what factors are included in the service excellence based on corporate entrepreneurship, whether these factors affect the patient satisfaction, and which factors that influencing dominantly to patient satisfaction. The research design of this study is exploratory quantitative approach, which is conducted in two stages. The first step, the research conducted by open-ended question to explore the perception of the 40 patients about the service excellence of the hospital, so it can be known the factors which include in service excellence based on corporate enterpreneurship can be developed in the improvement of health services at the Dr. Soetomo Hospital after the implementation of BPJS, then proceed with a structure close-ended question to 400 patient of Health-BPJS. The sampling technique was by purposive non-random sampling. The result of this study are, first, factors affecting patient satisfaction of Health-BPJS participant after get treatment at the government hospital (Dr. Soetomo Hospital and Hajj Public Hospital) formed by six factors. Factors that formed was named by the reliability factor, empathy factor, the factor means of support, administrative factors, service factors, and factors of hospital hygiene. Second, indicators with the highest loading values obtained from the rotation calculation factors are indicators of $\mathrm{X}_{13}$ on the reliability factor is the health services infrastructure supported by sophisticated technology.
\end{abstract}

Keywords: Satisfaction, Corporate Enterpreneurship

\section{Introduction}

Hospital is health care providers involved in the implementation of UHC (Universal Health Coverage) which is a national program of the government. Improving the quality of hospital services is important in order to meet the needs of patients. The UHC program find the problem in the field of the health service, for example lengthy of administrative process, lack of medical personnel, as well as the public health infrastructure is still a shortage (1).

Ashish Jha, professor of health policy at Harvard University School of Public Health, the result of his study suggests that more than 40 million people worldwide are harmed by poor hospital care every year, mainly in developing countries (http://www.voaindonesia.com). Puspitasari and Arifianty (2) research's findings show patient in hospital $\mathrm{X}$ in Indonesia complained to medical personnel who are less communicative, less friendly personnel, cleanliness less intact, slow service, doctors can rarely be met, damage to facilities, and other complaints. It can be seen that there are still many patients who are not satisfied with the service of hospital X.

Punnakitikashem et al. (3) in Mohebifar et al., (4) notes that the hospital began to realize the importance of measuring, monitoring, and improving the quality of health services to provide patient satisfaction. The provision of high quality services also becomes important to achieve the Millennium Development. The hospital managers underlined the main objective to attract many patients and make them become loyalty by meet the expectations of the patient and try to respond them effectively, therefore, hospital managers need to understand the overall on how to improve service quality (5)in (4).

Superior service quality is the key to gain an excellence competitive in the service industry. The customer satisfaction depends on their perception of service quality and their trust to company service providers (6-8) in (9). Patients have a hope in a health service hospital and demanded the accuracy, reliability, responsiveness, and empathy $(8,10,11)$ in (12). The company will revive customer perception of service quality by providing better quality services to customers (9), therefore, the hospital management needs to understand the concept of corporate entrepreneurship.

Corporate entrepreneurship refers to activities such as innovation, risk taking, and strategic renewal in the company (13) in (14). Organizations must adapt to survive, compete, due to customer demand and changes in the economic environment. Schumpeter defines corporate entrepreneurship as creative destruction in which companies make changes, both in products and production methods (15). One of the advantage of corporate entrepreneurship is their closeness to customers because of the innovation (16)in (15). Because of the corporate entrepreneurship concept, a hospital needs to do a better service for their patient, and make the patient as the priority to be served even patients who use the facilities Helath-BPJS that have proceeded.

\section{Literature Review}

\subsection{Service Quality}


Service quality is a combination of service attributes or the dimension of customers need (17) in (18). Service quality is more difficult to understand if compared to products that are visible physically because the judgment depends on the individual attitudes and perceptions (18). One way that service providers can do to differentiate their services from competitors is providing the best- service quality $(19,20)$ in $(18)$.

Yuen and Thai (18) suggests that service quality is an important factor in influencing customer satisfaction. Service quality and customer satisfaction is an important factor for choosing the next company's, whether consumers continue to use the service at the same company or switch to another company $(8,21,22)$ in (23). Numerous research show that by increasing the service quality, the company is able to satisfy their customers and maintain the customer loyalty(9).

\subsection{Service Excellence Quality}

Mohebifar et al. (10) explains that in order to evaluate the satisfaction and customer expectations of service quality, SERVQUAL models has been used that introduced by Parasuraman and Zeithaml (24) SERVQUAL is comparing the service expectations which will be accepted by customers and the actual service received (25). If the reality is more than expected, the quality of service can be said excellent, but if the reality was less than expected, then the service is said to be inferior. And if the fact is same with the hope, so the service is satisfactory. Thus the service quality can be defined as the extent of the difference between reality and expectations of customers to the services they receive. The expectations of the customers are essentially same as the service which provided by the company to customers. The expectation of customers is based on information by word of mouth, personal needs, past experience, and external communications (advertising and various promotion of other companies).

\subsection{Customer Satisfaction}

Consumer satisfaction is regarding the quality associated with the company's core services, which the satisfaction reflects to the customer experience with the service. Improving the quality which is not suitable with consumer's needs, it will not make the customer satisfied(18). In the marketing literature, customer satisfaction can lead to a positive attitude on consumer behavior (26)in (18). Consumers who are satisfied are more likely to show loyalty to the company to re-use the company's services or recommend to others (27) in (18). Satisfaction is defined by (28) in (29) as happy feeling or disappointed which the result of the comparison of the real performance of a product (as a result) with the expectations. Satisfaction means the providing of goods and services by a company may cause certain valuation by consumers, so consumers remain positively engaged with the company (30), in $\mathrm{Lu}$ et al., (31). also suggested that satisfaction is a positive attitude of consumers towards the product or service that could increase the repeat purchases.

High satisfaction means that the company's performance is actually better than the customers expectations, which causes the customer to use or buy the same products or services again $(32,33)$ in (31). When the company's performance is not the same or worse than customers expectations, so customers will not be satisfied so it will appears negative response (34) in (31). Dissatisfaction makes consumers leave the company with a negative attitude that relevant to the will not make repeat purchases attitude (33) in (31). Customers who are not satisfied with the service quality will express their dissatisfaction to the company directly. Customers even spread negative word-of-mouth to others, especially the era of information technology which enables the spreading of negative word-of-mouth over the internet. Customers who are not satisfied remain to have a negative attitude towards any service recovery strategies by companies (35). It can also decrease the desire of customers to use the services of these companies $(36,37)$ in $(35)$.
Patients who are not satisfied with the quality of hospital services would look for other hospitals. Service quality is now a demand from customers. Feedback and customer expectations have a major role in improving the quality of service and increasing customer satisfaction (38). Zamazalová (39) in (40) suggests the factors that affect customer satisfaction is the product (in terms of product quality, availability, etc.), price, service, distribution systems, and product image.

\subsection{Corporate Entrepreneurship}

Contemporary entrepreneurship researches have started with research of economist Joseph Schumpeter in 1883-1950. Schumpeter defines the entrepreneurship as a "creative destruction" process in which entrepreneurs change continuously the current products or production methods with news or destroys(15). Lumpkin and Dess(41) in (15) have defined the corporate entrepreneurship as a "new entry" referring the first entry to new or established market with new or current goods/services. Corporate entrepreneurship includes to the product innovation, risk taking, and proactive behaving (42) in (15).

Corporate entrepreneurship is a process, in which product, service, or innovative methods are established by creating an entrepreneurial culture in an organization (43) in (44). Corporate entrepreneurship can be defined as running a new business in developing corporates in form of internal innovation, joint measures or ownership, modernization of products and processes, and management of innovations (45), in (44). (44) define the term corporate entrepreneurship as a process that goes on within a founded firm, regardless of its size, and leads not only to new business ventures but also to other innovative activities and orientations such as development of new products, services, technologies, managerial techniques, strategies and competitive postures. Several researches have identified someindicators that are considered as manifest of entrepreneurial behavior. These include innovation, risk-taking, productiveness, and competitive aggressiveness (15).

\section{Results and Discussions}

This study is using factor analysis that aim to explore new indicators that form factor. Model or factor analysis techniques, using Principal Component Analysis (PCA). The result of the calculation according to Maholtra (46), there are several key statistics, among others: the Bartlett's test of Sphericity, which is used to test the interdependence between the grains as an indicator or factor. This analysis intends to determine indicators that are not correlated with each other (colinearity) in the population. If proved, there are indicators that are correlated then one of these indicators do not need to be analyzed. While Keiser-Meyer Olkin (KMO) measure of sampling adequacy, is an index number to compare the magnitude of the correlation coefficient between observations with a partial correlation coefficient. The result of the calculation is as follow Table 5.5

Value of Keiser-Meyer Olkin (KMO) measure of sampling adequacy calculation result is $0.621>0.5$, which means that the correlation between the indicators can explain other indicators and analysis of appropriate factors to be used as an analysis tool. Research results in Table 5.8 shows the components that form factor six. It shows there are six factors that formed from the rotation factor. Component factors stop the eigenvalue of 1.140. Table 5.9. Percentage of variance, ie a total of variance explained these attributes. The attributes of each factor is $61.379 \%$. This value is more than $50 \%$ so the factor formed by the analysis process can be accepted.Matrix factors is factor that contain of factor loadings of all indicators on all the factors that have been chosen. From this matrix of factors can be seen the influence of an indicator to the factors. The result of component matrix calculation can be seen in Table 5.9 which indicates there are six factors formed. Component matrix is a factor process in the placement of each factor, but at 
this stage is the rotation process has not been maximal yet, so there are factors that do not contain indicators. To ensure the indicators are spreaded on different factors need to be done by rotation. The rotation techniques which used is varimax. This rotation technique is most often used technique. Here are the results of the calculation of the rotation factor more Table 5.11

The calculation result of factors rotation indicate there are 6 factors formed. In the factors rotation that can be interpreted if the loading factor has a value of more than 0.5 .

1. The first factor that has greater value than 0.5 is on $\mathrm{X}_{3}, \mathrm{X}_{7}$, $\mathrm{X}_{10}, \mathrm{X}_{13}, \mathrm{X}_{14}$ and $\mathrm{X}_{15}$ indicators.

2. The second factor that has greater value than 0.5 is on $X_{1}$, $\mathrm{X}_{2}$, and $\mathrm{X}_{8}$ indicators.

3. The third factor that has greater value than 0.5 is on the $X_{16}$ indicator.

4. The fourth factor that has greater value than 0.5 is on $\mathrm{X}_{5}, \mathrm{X}_{18}$ and $\mathrm{X}_{19}$ indicators.

5. The fifth factor that has greater value than 0.5 is on $\mathrm{X}_{6}$ and $\mathrm{X}_{17}$ indicators.

6. The sixth factor that has greater value than 0.5 is on $\mathrm{X}_{4}, \mathrm{X}_{11}$ and $\mathrm{X}_{12}$ indicators.

After rotation factor phase, the next step interpret the factors. This step aims to determine which indicators can be included in a factor and which one is not included in a factor. Naming each factor in this study use surrogate methods, that is the named factor method based on the highest value of the factor loading on each factor formed. Therefore, there are six factors formed which influence patient satisfaction of patient Health-BPJS after check up at the government hospital (Dr. Soetomo Hospital and Hajj Public Hospital)

The first factor that has a value greater than 0.5 on skill and knowledge indicator of the medical team for treating patients already good $\left(\mathrm{X}_{3}\right)$, the information from the medical team delivered a clear and easy to understand the patient / family $\left(\mathrm{X}_{7}\right)$, the medical team provide the services to the patient quickly $\left(\mathrm{X}_{10}\right)$, health services infrastructure supported by sophisticated technology $\left(X_{13}\right)$, officers who provide services to patients is on time $\left(\mathrm{X}_{14}\right)$, and medical team in providing services to patients able to well communicate $\left(\mathrm{X}_{15}\right)$. The highest factor loading value lies on the thirteenth indicator $\left(\mathrm{X}_{13}\right)$ with a loading value of 0.790 . The indicator refers to the health services infrastructure supported by sophisticated technology. Based on these indicators, the first factor is called the reliability factor.

The second factor that has a value of more than 0.5 on friendliness indicator of medical personnel who provide the service to patients $\left(\mathrm{X}_{1}\right)$, the medical team in providing services to patients is polite $\left(\mathrm{X}_{2}\right)$, and the hospital has complete facilities and infrastructure $\left(\mathrm{X}_{8}\right)$. The highest factor loading value lies on the second indicator $\left(\mathrm{X}_{2}\right)$ with a value of 0.764 loading. The indicator is about the politeness medical team in providing services to patients. Based on these indicators, it is called empathy factor.

The third factor that has a value of more than 0.5 on enough parking space indicator $\left(\mathrm{X}_{16}\right)$, with the value of the loading factor of 0.620. The indicator is about the parking space which is large enough. Based on these indicators, it is called supporting facilities factor. The fourth factor that has a value of more than 0.5 on easy of technical and administrative requirements that must be fullfilled indicator $\left(\mathrm{X}_{5}\right)$, medical equipment is clean / hygienic $\left(\mathrm{X}_{18}\right)$ and laboratory service queue was not too long $\left(\mathrm{X}_{19}\right)$. The highest factor loading value lies on the nineteenth indicator $\left(\mathrm{X}_{19}\right)$ with a value of 0.677 loading. That indicator is about the laboratory service queues which are not too long. Based on these indicators, it is called administrative factors.

The fifth factor that has a value of more than 0.5 on the indicator of patient service time suit to the schedule (X6) and medical team is fair in providing services to patients (X17). The highest factor loading value lies on sixth indicator (X6) with values loading 0,820 . The indicators regard to patient service time suit to the schedule. Based on these indicators, it is called the service factor. The sixth factor that has a value of more than 0.5 on the indicator of service flow were easy to understand (X4), the halls of the hos- pital, waiting rooms, and cleanliness and discipline were good (X11) and the cleanliness of the room was good (X12). The highest loading factor value lies on the twelfth indicator (X12) with a value loading 0,755 . The indicator regard to the cleanliness of the rooms were already good. Based on these indicator, it is called hospital hygiene factor.

\section{Conclusion}

Factors affecting patient satisfaction of Health-BPJS participant after get treatment at the government hospital (Dr. Soetomo Hospital and Hajj Public Hospital) formed by six factors. Factors that formed was named by the reliability factor, empathy factor, the factor means of support, administrative factors, service factors, and factors of hospital hygiene. Indicators with the highest loading values obtained from the rotation calculation factors are indicators of X13 on the reliability factor is the health services infrastructure supported by sophisticated technology.

\section{Acknowledgement}

This work was supported by Faculty of Economics and Business, Universitas Airlangga.

\section{References}

[1] Handayani PW, Hidayanto AN, Sandhyaduhita PI, Ayuningtyas D. Strategic hospital services quality analysis in Indonesia. Expert Systems with Applications. 2015;42(6):3067-78.

[2] Puspitasari NB, Arifianty MS. PENGARUH KUALITAS PELAYANAN TERHADAP KEPUASAN PASIEN TERHADAP KELUHAN DAN LOYALITAS PASIEN RAWAT INAP. Prosiding SNST Fakultas Teknik. 2016;1(1).

[3] Punnakitikashem P, Buavaraporn N, Maluesri P, Leelartapin K, editors. Health care service quality: Case example of a hospital with lean implementation. POMS 23rd Annual Conference, Chicago, IL, USA; 2012.

[4] Mohebifar R, Hasani H, Barikani A, Rafiei S. Evaluating service quality from patients' perceptions: Application of importance-performance analysis method. Osong public health and research perspectives. 2016;7(4):233-8.

[5] Sodani PR, Kumar RK, Srivastava J, Sharma L. Measuring patient satisfaction: A case study to improve quality of care at public health facilities. Indian journal of community medicine: official publication of Indian Association of Preventive \& Social Medicine. 2010;35(1):52.

[6] Ismail I, Haron H, Nasir Ibrahim D, Mohd Isa S. Service quality, client satisfaction and loyalty towards audit firms: Perceptions of Malaysian public listed companies. Managerial auditing journal. 2006;21(7):738-56

[7] Aydin S, Özer G. The analysis of antecedents of customer loyalty in the Turkish mobile telecommunication market. European Journal of marketing. 2005;39(7/8):910-25.

[8] Parasuraman A, Zeithaml VA, Berry LL. Servqual: A multiple-item scale for measuring consumer perc. Journal of retailing. 1988;64(1):12.

[9] Khan MM, Fasih M. Impact of Service Quality on Customer Satisfaction and Customer Loyalty: Evidence from Banking Sector. Pakistan Journal of Commerce \& Social Sciences. 2014;8(2).

[10] Oliver RL, Rust RT, Varki S. Customer delight: foundations, findings, and managerial insight. Journal of retailing. 1997;73(3):311-36. 
[11] Brady MK, Cronin Jr JJ. Some new thoughts on conceptualizing perceived service quality: a hierarchical approach. Journal of marketing. 2001;65(3):34-49.

[12] Jandavath RKN, Byram A. Healthcare service quality effect on patient satisfaction and behavioural intentions in corporate hospitals in India. International Journal of Pharmaceutical and Healthcare Marketing. 2016;10(1):48-74.

[13] Zahra SA. Goverance, ownership, and corporate entrepreneurship: The moderating impact of industry technological opportunities. Academy of management journal. 1996;39(6):1713-35.

[14] Sakhdari K. Corporate Entrepreneurship: A Review and Future Research Agenda. Technology Innovation Management Review. 2016;6(8)

[15] Kaya N. Corporate entrepreneurship, generic competitive strategies, and firm performance in small and medium-sized enterprises. Procedia-Social and Behavioral Sciences. 2015;207:662-8.

[16] Nooteboom B. Firm size effects on transaction costs. Small Business Economics. 1993;5(4):283-95.

[17] Zeithaml VA, Parasuraman A, Berry LL. Delivering quality service: Balancing customer perceptions and expectations: Simon and Schuster; 1990.

[18] Yuen KF, Thai VV. Service quality and customer satisfaction in liner shipping. International Journal of Quality and Service Sciences. 2015;7(2/3):170-83.

[19] Dadfar H, Brege S. Differentiation by improving quality of services at the last touch point: the case of Tehran pharmacies. International Journal of Quality and Service Sciences. 2012;4(4):345-63.

[20] Collett Miles P. Competitive strategy: the link between service characteristics and customer satisfaction. International Journal of Quality and Service Sciences. 2013;5(4):395-414.

[21] Grönroos C. A service quality model and its marketing implications. European Journal of marketing. 1984;18(4):36-44

[22] Lewis R, Booms H. The Marketing of Service Quality: In emerging Perspectives on Service Marketing, eds. Berry, L, Shostack, G, and Upah, G, AMA, Chicago. 1983.

[23] 23. Akdag H, Kalaycı T, Karagöz S, Zülfikar H, Giz D. The evaluation of hospital service quality by fuzzy MCDM. Applied Soft Computing. 2014;23:23948.

[24] Parasuraman A, Zeithaml VA, Berry LL. A conceptual model of service quality and its implications for future research. the Journal of Marketing. 1985:41-50.

[25] 25. de Waal A, de Waal A, van der Heijden B, van der Heijden B. Increasing customer loyalty and customer intimacy by improving the behavior of employees. Journal of Strategy and Management. 2016;9(4):492-510.

[26] 26. Qin H, Prybutok VR. Service quality, customer satisfaction, and behavioral intentions in fastfood restaurants. International Journal of Quality and Service Sciences. 2009;1(1):78-95.

[27] Senić V, Marinković V. Examining the effect of different components of customer value on attitudinal loyalty and behavioral intentions. International Journal of Quality and Service Sciences. 2014;6(2/3):134-42.

[28] Kotler P. Marketing management millenium edition. Marketing Management. 2000;23(6):188-93

[29] Tweneboah-Koduah E, Farley AYD. Relationship between customer satisfaction and customer loyalty in the retail banking sector of Ghana. International Journal of Business and Management. 2015;11(1):249.
[30] Wicks AM, Roethlein CJ. A satisfaction-based definition of quality. The Journal of Business and Economic Studies. 2009;15(1):82.

[31] Lu C, Berchoux C, Marek MW, Chen B. Service quality and customer satisfaction: qualitative research implications for luxury hotels. International Journal of Culture, Tourism and Hospitality Research. 2015;9(2):168-82.

[32] Oliver RL. A cognitive model of the antecedents and consequences of satisfaction decisions. Journal of marketing research. 1980:460-9.

[33] Williams J, editor The student satisfaction approach: Student feedback and its potential role in quality assessment and enhancement2002: 24th EAIR Forum. Prague.

[34] Hirschman AO. Exit, voice, and loyalty: Responses to decline in firms, organizations, and states: Harvard university press; 1970

[35] Presi C, Saridakis C, Hartmans S. User-generated content behaviour of the dissatisfied service customer. European Journal of Marketing. 2014;48(9/10):160025

[36] Lee J, Park D-H, Han I. The effect of negative online consumer reviews on product attitude: An information processing view. Electronic commerce research and applications. 2008;7(3):341-52.

[37] Ye Q, Law R, Gu B, Chen W. The influence of usergenerated content on traveler behavior: An empirical investigation on the effects of e-word-of-mouth to hotel online bookings. Computers in Human Behavior. 2011;27(2):634-9.

[38] Fajri IK, Wajdi MF. Analisis Pengaruh Kualitas Pelayanan Kesehatan Terhadap Kepuasan Pasien Di Rumah Sakit Umum Daerah Kabupaten Karanganyar: Universitas Muhammadiyah Surakarta; 2016.

[39] ZAMAZALOVÁ M. Spokojenost zákazníka. Acta Oeconomica Pragensia. 2008;16(4):76-82.

[40] Suchánek P, Richter J, Králová M. Customer satisfaction, product quality and performance of companies. Review of Economic Perspectives. 2014;14(4):329-44.

[41] Lumpkin GT, G.G D. Clarifying the Entrepreneurial Orientation Construct and Linking it to Performance. Academy of Management Review. 1996;21:135-72.

[42] J.G. C, Slevin DP. A Conceptual Model of Entrepreneurship as Firm Behavior, Entrepreneurship Theory and Practice. 1991;16:7-25.

[43] Fry FL. Entrepreneurship: a planning approach: West Group; 1993.

[44] Ziyae B. Presenting an evaluation model of human resource management's effect on corporate entrepreneurship. World Journal of Entrepreneurship, Management and Sustainable Development. 2016;12(3):228-42

[45] Ergün E, Bulut Ç, Alpkan L, Çakar ND. Connecting the link between corporate entrepreneurship and innovative performance. Global Business and Technology Association Proceedings. 2004.

[46] Malhotra NK. Basic Marketing Research: Pearson New International Edition: Leeds University Business School: Pearson Higher Ed; 2013. 